\title{
ポリウレタンの表面改質 一高次構造制御と摩擦・摩耗特性-
}

\section{1.は じ めに}

ポリウレタンエラストマー(PUE) は分子設計しやすく かつ力学物性, 耐摩耗性, 耐油性, 抗血栓性等に優れてい るために，工業材料から医用材料まで広い分野で用いられ ている。しかし，未だ耐熱性，耐加水分解性，機能付与等 改善すべき点が多く，より一層の高性能化が期待されてい る.

本稿ではPUEの表面改質について最近の研究を概観し, 我々が行っているPUEの表層部に第 2 成分モノマーを導 入・反応させ，ブリードを生じることなく，また，PUE 本来の優れた力学物性を損なうことなく，安定した性能を 発揮する低摩擦係数, 高耐摩耗性PUEの開発研究につい て紹介する。.

\section{2. 最近の研究}

医用材料としてのPUEの親水性や抗血栓性を改質する ため，表面改質の研究が広くなされている ${ }^{1-7)}$. 一方， PUE 製品は，例えば，電子複写機内において，残留トナ 一を除去するためのクリーニングブレードとして，感光体 ドラムと接触して使用されている。このように $\mathrm{OA}$ 関連機 器等の精密機器内においては, その中心部品と直接接触し て使用されることが多いため，ブリードにより污染されな いことが製品設計上の制約条件となる ${ }^{8,9)}$ ．この要求を満 たしながら，摩擦係数の低減，耐摩耗性の向上，および帯 電性の低減化を計るためにはPUEの表面改質が必要とな る.

PUEの表面改質は多くの方法により行われている．第 一に，原料であるポリオール，ジイソシアナート，鎖延長 剂に改質成分となる構造を導入する方法があげられる。非 極性のヒドロキシ末端ポリイソプレン (HTPIB) でのポリ (オキシテトラメチレン)グリコール (PTMG)の一部の置 換 ${ }^{10)}$ ，ポリオールの混合 ${ }^{11)}$ ，フッ素原子を導入したポリ オール12）やジイソシアナート 13) の例がある. 第二に,
PUE表面への改質成分の導入として，グラフト化や塗布， 相互貫入網目 $(\mathrm{IPN})$ 法がある。また，鎖延長剤にジーエチ ルビス (ヒドロキシルメチルマレイン酸エステル)を用いた 後，側鎖を加水分解し，ポリ（エチレンオキシド）(PEO) や水酸基，アミノ基，スルホン酸基等の側鎖への導入があ $3^{20)}$. PUE表面にマイグレートできるフッ素含有マクロ マーによる改質も報告されている ${ }^{21)}$. 我々はメ夕クリロ イルイソシアナート (MAI)によるIPN化 ${ }^{22)}$ やイオン性モ ノマーの電気泳動法による傾斜 IPN化による表面改質 ${ }^{23)}$ を行い, 摩擦係数の低下や耐摩耗性の向上を達成し, 改質 による試料表面の架橋密度上昇の効果とPUEにおける分 子間凝集力の確保のバランスが重要であることを明らかに した.

\section{3. ポリメリック MDI(PMDI)による表面改質 ${ }^{24)}$}

基材PUEには $2 \mathrm{~mm}$ 厚のエーテル系ポリオールである PTMG $(M n=2037)$ あるいはエステル系ポリオールである ポリ(エチレンアジペート)グリコール (PEA：Mn=2015) $-4,4$-ジフェニルメタンジイソシアナート (MDI)-1,4-ブ タンジオール $(\mathrm{BD}) /$ /トメチロールプロパン (TMP) (重量 比 75/25)の 2 種類のPUEを用い, ポリメリック MDI (PMDI ; NCO 含有率 $30.8 \mathrm{wt} \%$, 粘度 $100 \sim 250 \mathrm{cP} / 25^{\circ} \mathrm{C}$ ) (図 1)に窒素雲囲気にて $50 \pm 2{ }^{\circ} \mathrm{C}$ で 4 150 分間浸せきし 含浸させた。試料を取り出した後 $110^{\circ} \mathrm{C}$ で加熱し，アロハ ナート結合を生成させた。 その後，未反応イソシアナート

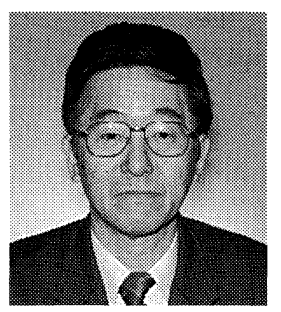

*長崎大学大学院生産科学研究科物質科学専攻 （852-8521 長崎市文教町 1-14）教授・工博. 1970 年九州大学大学院工学科応用化学専攻修 士課程修了, 出光石油化学(侏をを経て 1972 年 長崎大学工学部材料工学科助手. 同講師, 助 教授を経て 1993 年教授. 2001 年より現職. 専門は高分子材料学, 特にポリウレタン科 学; 現在, 日本ゴム協会理事，マテリアルラ イフ学会常任理事, 高分子学会九州支部理事, ポリウレタン研究会主宰等. 


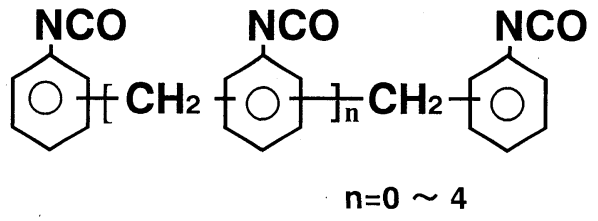

図 1 ポリメリック MDI(PMDI)の構造

基をアルコールで失活させることにより, 表面改質 PUE を得た。

PMDIで処理したPUEの外観は未改質PUEの白色半透 明から不透明な淡黄色あるいは薄茶色となった。 2 種類の PUEを同一時間，同一温度のPMDIに浸せきしたところ， PMDIの含浸率はPUEとの相溶性を反映して異なり，エ ーテル系PTMG-PUEのそれはエステル系PEA-PUEよ り 2 倍以上高い值を示した. JIS-A 硬度はPMDI処理によ り両PUEとも約 3 度上昇したが，これは高高いPMDIを 含浸したこと, 更に, PMDIがPUEのウレタン基や残存 イソシアナート基の修飾剤であるメタノールと反応するこ とによって, 剛直な構造のアロハナート結合や凝集力の高 いウレタン結合を生成したためである.

改質層の厚さはPMDI含量 $1.37 \mathrm{wt} \%$ の PEA-PUE で 380 $\mu \mathrm{m}, 3.41 \mathrm{wt} \%$ PTMG-PUEで $400 \mu \mathrm{m}$ である。また， 改質層および未改質層のいずれにも球晶が存在し, その直 径はPEA-PUEでは 15〜20 $\mu \mathrm{m}$, PTMG-PUEでは25〜 $35 \mu \mathrm{m}$ であり, 基材PUEに見られた球晶と同様の大きさ と構造を有している。この改質層は $75{ }^{\circ} \mathrm{C}$ 付近まで安定に 維持され, 偏光顕微鏡での観察では $200{ }^{\circ} \mathrm{C}$ 付近に至るまで 徐々に着色状態が変化した。このことにより，PUEの通 常の使用雲囲気下ではブリードや性能変化の問題を生じな い材料を得ることができたといえる.

改質層の $\mathrm{Tg}$ はごく僅か $\left(1{ }^{\circ} \mathrm{C}\right.$ 程度) 上昇し, $200{ }^{\circ} \mathrm{C}$ 付近 のハードセグメントの融解温度は変化しなかった。この結 果より, PMDIは球晶のモルホロジーを破壞することなく， ソフトセグメントリッチ相あるいはハードセグメントとソ フトセグメントの混合相を中心に含浸していることがわか る.また，上述の改質層においても球晶の存在が確認され たことに加えて、メタノールキャップしたPMDIのDSC 曲線において見られる $30 \sim 1500^{\circ} \mathrm{C}$ の間の複数の融解の吸熱 ピークが，改質試料には見られなかったことから，PMDI はPUE表面を覆うように単独層を形成しているのではな く, PUE網目中に導入されていることがわかる.

改質層の弾性率は上昇し, 破断強度㧍よび破断伸びは PEA-PUEでは著しく低下するが，PTMG-PUEでは PEA-PUEほどの低下を示さない。これはPMDI含浸によ る硬度の上昇と改質層に㧍けるソフトセグメントの伸長配 向・凝集の阻害に基づくが，エーテル系ポリオールの PTMG はエステル系ポリオールのPEAに比較して伸長配 向し難いため，その影響が少ないと考えられる.

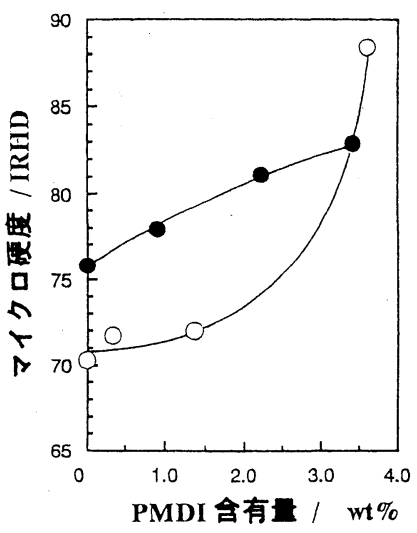

図 2 マイクロ硬度へのPMDI含有量の影響 $\bigcirc$ PEA-PUE $\bigcirc$ PTMG-PUE

PMDI含有量が表層部近傍のマイクロ硬度に与える影響 を図 2 に示す。嵩高く剛直な構造を有するPMDIの含有量 が3.0wt\%に増加すると，マイクロ硬度はPEA-PUEでは コントロールの70から 79 に急激に, PTMG-PUEではコ ントロールの 76 から 82 に緩やかに上昇する。この上昇傾 向の相違は先に述べたように，PMDI との相溶性が大きく 影響している.PEA-PUEではPMDI との相溶性が小さい ため, 含浸したPMDIが熱処理中に表面層に移行して，よ り表層部近傍のPMDI濃度が上昇し，マイクロ硬度の上昇 は急激となる。一方，PTMG-PUEでは表層部に含浸した PMDIが熱処理中に試料の内層部に移行し，表層部の PMDI濃度が低下するため, PMDI含量増加に伴いマイク 口硬度は穏やかに上昇すると考えられる．本研究で行った 条件下では, PMDI含有量がPEA-PUEでは 3 wt $\%$, PTMG-PUEでは $2 \mathrm{wt} \%$ 上゙昇しても，マイクロ硬度 は 80 程度であり，要求水準を十分に満たしている。

摩擦係数におよぼすPMDI含量の影響を図 3 に示す. PEA-PUEおよびPTMG-PUEのいずれも $1 \mathrm{wt} \%$ 以下と 少量のPMDIの含浸により摩擦係数は著しく低下する.し かし, PMDI含量の増加に伴うょり一層の摩擦係数の低下 傾向は認められず，逆にPEA-PUEにおいては，摩擦係

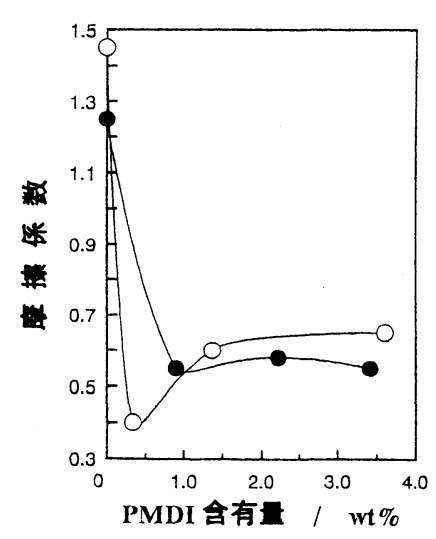

図 3 摩擦係数へのPMDI含有量の影響

$\bigcirc$ PEA-PUE $\bigcirc$ PTMG-PUE 
数がわずかに増加する. 少量のPMDIの含浸による摩擦係 数の著しい低下は，PMDIの侵入により試料表面の硬度が 上昇し，摩擦抵抗が低下したためと考える。しかし，摩擦 試験の荷重 $(100 \mathrm{~g})$ が比較的小さいことから，摩擦係数は 試料のごく表面近傍の硬さの影響しか受けず，試料深さ方 向の硬度変化に左右されないため, PMDI含量の上昇に伴 う一層の低下は認められなかったと考える．PEA-PUEに おいては，PMDI含量の増加によって摩擦係数が上昇する 傾向が見られるが，PEA-PUEとPMDI-PUEとの相溶性 が低いため，熱処理時に試料内部より一部PMDIがブリー ドし，試料表面の平滑性を低下させたことに起因すると考 えられる。

DIN 摩耗試験によって評価した摩耗体積は，図 4 に示 すようにいずれの系においても PMDI含量の増加に伴い減 少し, 耐摩耗性が向上する。 また，基材 PUEの摩耗面と 最も良好な耐摩耗性を示した改質PUEの摩耗面のSEM写 真において，PEA-PUEでは未改質および改質PUEとも 類似した摩耗痕が観察され，PMDI含浸に伴う摩耗形態の 変化は認められない。一方，PTMG-PUEでは改質に伴い 筋状の摩耗痕が観察される。DIN 摩耗試験によって評価 した耐摩耗性の向上は, PMDI含浸による硬度および架橋 密度の上昇効果拉よび残存イソシアナート基をメタノール で修飾したことによる凝集力の強いウレタン結合の生成効 果によると考えられる。

更に, より一層の摩擦係数の低下を狙い, PMDIを含浸, 熱処理後, 残存イソシアナートを $2,2,3,3,3$-ペンタ フルオロプロパノール $(\mathrm{PFPOH})$ 抢よび1-プロパノールで 修飾 (失活)させたPUEの摩擦係数とDIN 摩耗試験によっ て評価した耐摩耗性はいずれの系とも改善されたが，1プロパノールと PFPOH とには差が見られなかった。これ は，PFPOHのフッ素原子を有する炭素鎖が短いことやフ ッ素原子が改質部表面に選択的に配向していないこと等が 考えられる。

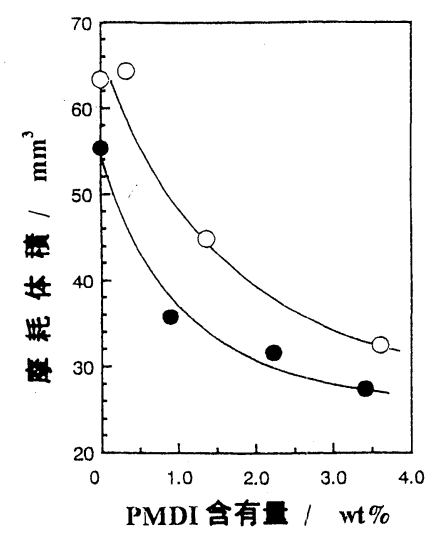

図 4 DIN 摩耗試験で評価した摩耗体積とPMDI含有量との関係 $\bigcirc$ PEA-PUE

\section{4. 含フッ素ポリメタクリレートとのIPN化によ る表面改質 ${ }^{25)}$}

フッ素原子は表面自由エネルギーを減少させるため, 高 分子材料の表面へフッ素を導入する研究がなされ，撥水・ 撥油性, 耐熱性, 耐薬品性等の性質の改善がなされている. 著者らは $1 \mathrm{H}, 1 \mathrm{H}, 5 \mathrm{H}$-オクタフルオロペンチルメタク リレート (OFPMA ; 図 5 )を用い，基材にPTMGを用い たPUEの表面層部分での相互貫入網目 (IPN) 化を行い PUE表面層の高次構造を制御することにより摩擦係数お よび耐摩耗性を改善した。

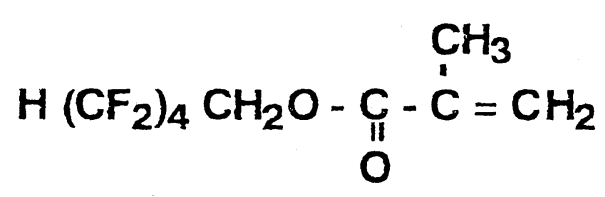

OFPMA

図 $51 \mathrm{H}, 1 \mathrm{H}, 5 \mathrm{H}$-オクタフルオロペンチルメタクリレート (OFPMA)の構造

得られた改質試料の外観はOFPMAが重合したPOFPMA の含有量の増加にしたがい, 白色半透明から淡緑黄色半透 明へと変化し，僅かに蛍光を示すようになる．PTMGPUE とOFPMAの相溶性は低く, 10 日間含浸させても, POFPMA 含有量は $18.8 \mathrm{wt} \%$ である。

OFPMAの含浸により，1157 $\mathrm{cm}^{-1}$ にC-F 伸縮振動吸収 と $962 \mathrm{~cm}^{-1}$ にメタクリル基の $\mathrm{C}=\mathrm{C}$ 伸縮振動吸収が観察さ れるが，重合後には $1157 \mathrm{~cm}^{-1}$ のC-F伸縮振動の吸収は変 化せず， $962 \mathrm{~cm}^{-1}$ の $\mathrm{C}=\mathrm{C}$ 伸縮振動の吸収が消失すること から，PUE表面に含浸したOFPMAの重合が進行してい ることがわかる。

POFPMA 含有量 $14.7 \mathrm{wt} \%$ の試料の改質層は偏光顕微鏡 写真により, 厚さ約 $350 \mu \mathrm{m}$ 程度の明るい改質層が観察さ れ，基材PUEに見られるものと同様の大きさ，形状，数 量の球晶が確認された。改質層は $190^{\circ} \mathrm{C}$ 付近まで安定に維 持され，この後，試料を室温まで泠却すると未改質層には 球晶が再生するが, 改質層では球晶は再生しない。これら の結果より, POFPMAも球晶の構造を破壊することなく, ソフトセグメントリッチ相あるいはハードセグメントとソ フトセグメントの混合相を中心に含浸しており，改質によ り生成したPOFPMAが球晶を形成するポリウレタンハー ドセグメントの再配列・凝集を阻害していると言える.

図 6 に表面改質試料の接触角におよぼすPOFPMA 含有 量の影響を示す．PUE 表面への微量 $(0.40 \mathrm{wt} \%)$ の POFPMAの含浸により，PUEの水の接触角は $93.6^{\circ}$ （基材PUE） から $104.5^{\circ}$ へと表面の撥水性が高くなり，PUE表面に POFPMA に由来するフッ素原子導入の効果が現れている 


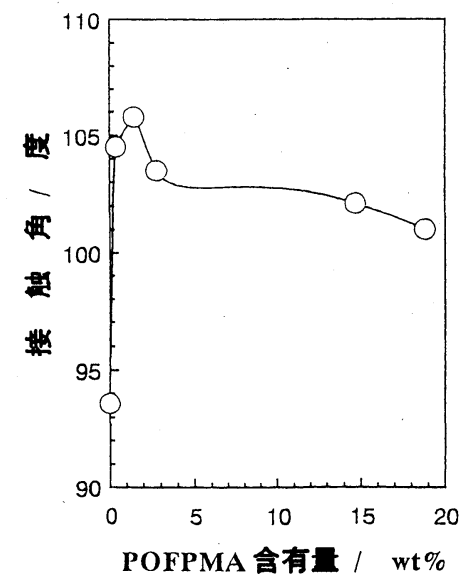

図 6 接触角とPOFPMA 含有量との関係

ことがわかる．しかし，POFPMAの含有量を増加させて も，一層の接触角上昇は認められず，逆に，わずかながら 接触角は低下する傾向を示している。これは，POFPMA 含量が増加しても試料の深さ方向 (試料内部)にPOFPMA が拡散し，PUE表面に存在するフッ素原子の量にほとん ど変化がないためである，また，PUEと OFPMAの相溶 性が本質的に低いため, OFPMA の含浸量を増加させると, 重合時に試料表面への OFPMAの移行(ブリード)が起こ り，改質表面の平滑性が低下し，接触角の低下を導くこと も考えられる。

図 7 に示すように，マイクロ硬度はPOFPMA含有量が $2 \sim 3 \mathrm{wt} \%$ までの領域において，未改質試料のそれより も低下し，更にPOFPMA の含有量が増加すると急激に上 昇する.POFPMAの含有量が摩擦係数におよぼす影響を 図 8 に,DIN摩耗試験によって評価した耐摩耗性におよ ぼす影響を図 9 に示す。困 8 の曲線と図 9 の曲線は同様の 傾向を示し，摩擦係数㧍よび耐摩耗性と POFPMA 含有量 との間に相関があることがわかる，摩擦・摩耗試験の結果 より, POFPMA含有量が 5 〜 $15 \mathrm{wt} \%$ で低い摩擦係数と高 耐摩耗性を示し, POFPMA 含有量には最適值があること がわかる。これらの結果は， $5 \mathrm{wt} \%$ 以の低POFPMA含

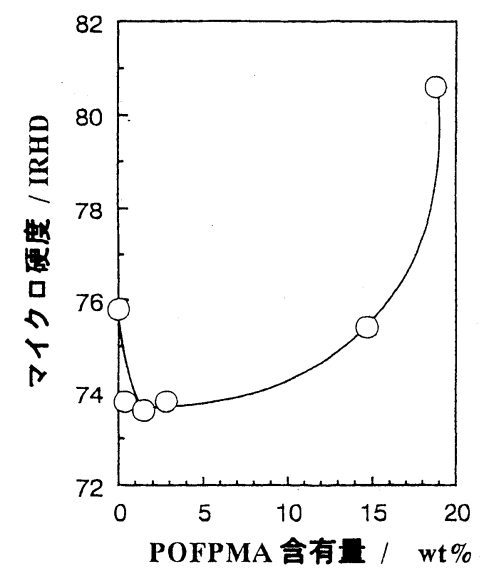

図 7 マイクロ硬度へのPOFPMA 含有量の影響

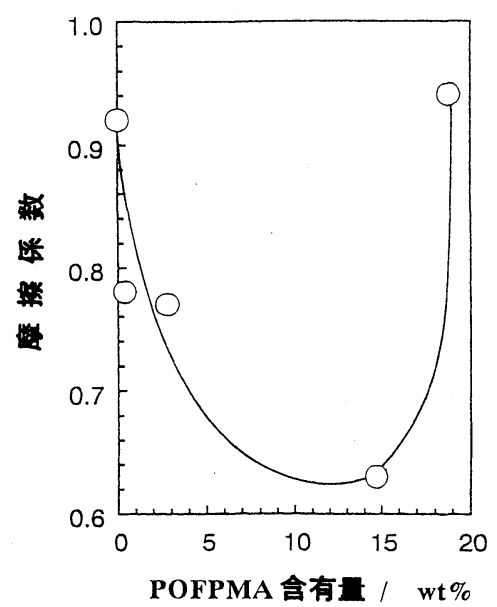

図 8 摩擦係数への POFPMA 含有量の影響

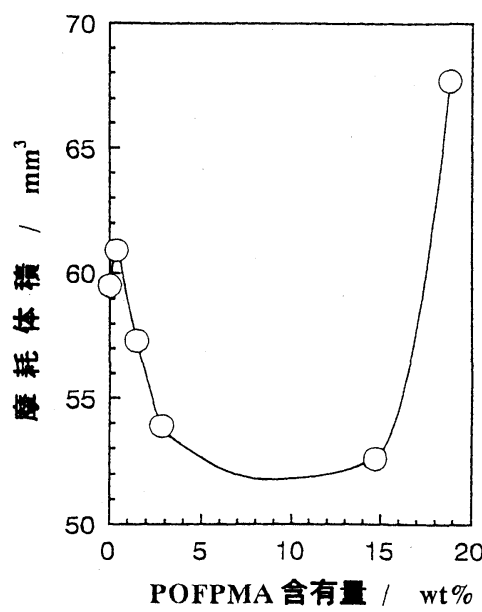

眓 9 DIN摩耗試験による摩耗体積と POFPMA 含有量との関係

有量域においては，少量のPOFPMAの分子鎖はPUEの 分子間凝集力を阻害する作用を示し，POFPMA本来の高 硬度で樹脂的な性質やPUEとのIPN化による見かけの架 橋密度上昇の効果を十分に発現していない。また，15 $\mathrm{wt} \%$ 以上の高POFPMA 含有量域に押いては，見かけの架 橋密度の上昇をもたらすとともに，接触角の測定結果から も示唆されるように，試料中に含浸したOFPMAが重合 時に試料表面に一部ブリードして，改質表面の平滑性を低 下させるため摩擦係数は增加の傾向を示す．耐摩耗性は, 本質的に分子間凝集力が低く，研磨材の刺激により削り取 られやすいPOFPMAの量が増加するため低下に転じると 説明できる。

DIN 摩耗試験後の摩耗面のSEM 写真 (図 10)より，少量 のPOFPMA を含浸させた試料では未改質試料と比較し て，わずかながら摩耗面の凹凸が減少し，より滑らかに摩 耗が進行している様子が見られるのに対して，POFPMA 含量が $18.8 \mathrm{wt} \%$ まで増加すると, 摩耗片(摩耗粉)が増加し, 研磨材走行に基づく筋状の摩耗痕が顕著になることより， 試料表面が容易に削られていることが推察される。

以上のことより，得られた表面改質PUEを OA 機器部 品材料として考察すると, 摩擦係数の低下㧍よび耐摩耗性 


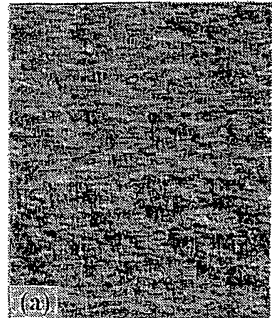

(POFPMA 0 Wt\%)

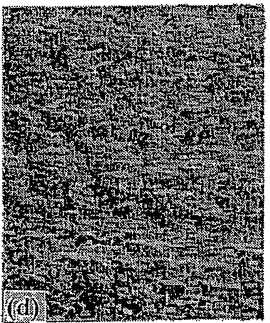

(POFPMA $281 w t \%)$

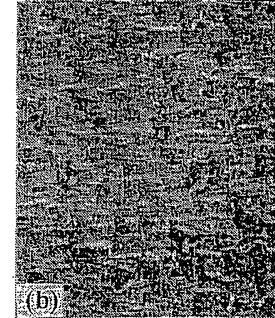

(POFPMA 0 40wt\%)

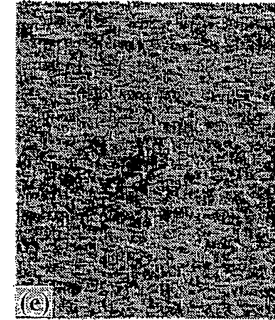

(POFPMA $147 w t \%)$

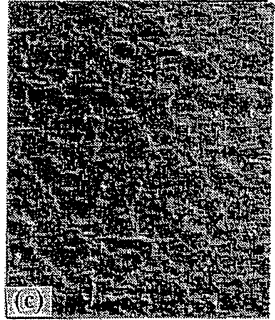

(POFPMA $149 w t \%)$

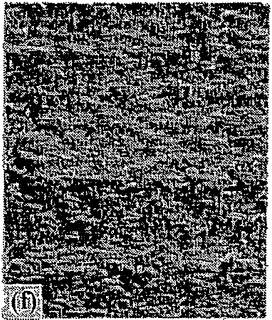

(POFPMA 18 8wt\%)

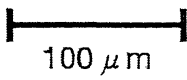

四 10 DIN 摩耗試験後の POFPMA 改質表面のSEM写真

の向上の点からは，POFPMA含有量 5〜 15wt\%が最適で あるといえる。しかしながら，加熱，重合時の OFPMA のブリードによる試料表面の平滑性低下の問題を回避する とともに，試料硬度の上昇の抑制，比較的高価なフッ素系 改質剤コストの低減を考慮すると, OFPMAの含浸率は 2 〜 $3 \mathrm{wt} \%$ 程度が適当であると考えられる。また，この含 浸率領域においてはOFPMAのフッ素原子の効果が効率 的に発揮され,摩耗の進行の仕方が滑らかであることから， 材料の摩耗がある程度進行した後でも性能を安定して維持 するとともにこれら材料が接触する相手材に損傷を与え， 故障を生じる可能性を低減することが期待できる.

\section{5.お わり に}

第二成分である改質剤の導入による見かけの架橋密度上 昇の効果と基材 PUEの分子間凝集力維持のバランスを最 適化することにより，基材 PUEの表層部に改質剤との IPN構造を有し，ブリードを生じず安定な性能を発揮する 低摩擦係数で高耐摩耗性PUEを得ることができた，工業 用材料, 特にOA 機器用伝動ベルトやクリーニングブレー ドへの応用では，材料は適度な柔軟性，屈曲性および弾性 を有し，相手材に傷などの損傷を与えないことが要求され る.したがって，JIS-A 硬度 90 以下に設計された材料が 大半を占めており, 今後より一層の低硬度化が推進される と予測され，表面改質技術が一層重要になるであろう。

\section{文献}

1 ) Lelah, M.D., Cooper, S. L. : Polyurethanes in Medcine, CRC Press, Boca Raton, FL, (1986)
2 ) Lee, J.H., Koepcek, J., Andrade, J. D. : Biomed. Mater. Res., 23, 351 (1989)

3 ) Brinkman, E., Poot, A., Van der Dose, L., Bantjes. A. : Biomaterials, 11, 200(1990)

4 ) Freij-Larsson, C., Wesslen, B. : J. Appl. Polym. Sci., 50, 345(1993)

5 ) Griesser, H, J. : Tissue Enginnering Intelligence Unit, 6 (Biomedical Applications of Polyurethane), 175 (2001)

6 ) Kleeli, D., Hocker,H. : Advances in Polymer Sci., 149, 1(1999)

7 ) Nakaya, T., Li, Y-J. : Recent Research Develpoments in Polymer Sci., 2000, 4, 53.

8 ）大谷利幸：ポリファイル，8，25(1989)

9 ) 入部敏之, 斉藤和雄, 国吉博, 桜井伸, 竹下真仁, 宮崎生吉, 五十嵐良作：NIKKEI NEW MATERIALS，8月24日号，68 (1992)

10) Goening, H., Gahde, J. : J. Mat, Sci. Lett., 17, 115(1998)

11) Bremner,T., Hill, D.J.T., et. al : J. Appl. Polym.Sci., 65, 939 (1997)

12) Chapman, T. M., Marra, K. G. : Macromolecules, 28, 2081(1995)

13) Lim, C. H., Choi, H, Noh, S. T. : Kongop Hwahak, 11, 371 (2000)

14) Wilson, D. J., Pond, R. C., Williams, R. L. : Interface Sci., 8, 389 (2000)

15) Hsu, S-H, Chen,W-C. : Biomaterials, 21, 359(2000)

16) Freji-lasson, C., Jannasch, P., et. al, : Biomaterials, 21, 307 (2000)

17) Guan, J., Gao, C., Feng, L., Shen, J. : J. Mat. Sci., Mat. in Medicine, 1, $447(2001)$

18) Inoue, H., Fujimoto, K., Uyama, Y., Ikada,Y. : J. Biomedical Materials Research, 35, 255 (1997)

19) Ishihara, K., Hanyuda, H., Nakabayashi, N. : Biomaterials, 16, 873 (1995)

20) Kang, I-K., Baek, D. K., et. al. : J. Polym. Sci., Polym., Chem., 36 $2331(1998)$

21) McCloskey, C. B., Yip, C. M., Santerre, J. P. : Macromoleclules, 35, 924 (2002)

22）古川睦久，岡崎貴彦，椎葉哲朗：日ゴム協誌，71，273(1998)

23) Zhang, Y., Furukawa, M. : Trans. Mat. Res. Soc. Japan, 26, 667 (2001)

24）古川睦久，岡崎貴彦，椎葉哲朗：日ゴム協誌，73，503(2000)

25）古川睦久，岡崎貴彦：日ゴム協誌，74，363(2001) 